\title{
Creating a path from emergency online teaching to sustainable online education
}

\section{Crear un camino desde la enseñanza en línea de emergencia a la educación en línea sostenible}

\author{
Diana Carolina Campaña Días. ${ }^{1}$, María Cristhina Robalino Araujo. ${ }^{2}$, Sandra Paulina Porras \\ Pumalema. ${ }^{3} \&$ Daniela Alejandra Bonilla Yucailla. ${ }^{4}$
}

\begin{abstract}
.
This article is a review of state-of-the-art literature related to the emergency online teaching practices that have taken place during the pandemic resulting from the spread of the COVID-19 virus. The authors move along, exploring how these emergency online-teaching practices could become sustainable online education. Nonetheless, in several cases, higher education institutions have had to adapt to, and adopt, specific strategies so that they have been able to transfer their face-to-face curriculum to a digital world - for which not everybody was prepared. Best practices are analyzed and proposed, aiming at offering language teachers and, in fact, educators from different fields, with criteria on how they could attain said sustainability, in the light that the current educational scenario, where online education has become ubiquitous, is bound to stay for longer than initially expected. The literature analysis demonstrates that, even though there are a number of teachers and institutions aligned with specific
\end{abstract}

1 Escuela Superior Politécnica de Chimborazo, Facultad de Salud Pública, Riobamba, Ecuador, diana.campania@espoch.edu.ec, (D) https://orcid.org/0000-0002-7608-4090

2 Escuela Superior Política del Chimborazo, Facultad de Recursos Naturales, Riobamba, Ecuador, cristhina.robalino@espoch.edu.ec, (D) https://orcid.org/0000-0002-1028-4882

3 Escuela Superior Politécnica de Chimborazo Facultad de Mecánica, Riobamba, Ecuador, sandra.porras@espoch.edu.ec, (D) https://orcid.org/0000-0001-6571-9938

4 Universidad Tecnológica Indoamérica, Departamento de Idiomas, Ambato, Ecuador, alejandrabonilla@uti.edu.ec, (D) https://orcid.org/0000-0002-3792-6937 
principles of online teaching, such as following and approaching online pedagogy, there is still room for improvement, more specifically in the use of authoring tools (such as video editors and other multimodal tools).

Keywords: COVID-19, Online EFL teaching, Emergency online teaching, Sustainable online education.

\section{Resumen.}

Este artículo es una revisión de literatura actualizada, relacionada con las prácticas de enseñanza online de emergencia que han tenido lugar durante la pandemia ocasionada por la propagación del virus COVID-19. Las autoras exploran cómo estas prácticas de enseñanza online de emergencia podrían convertirse en educación en línea sostenible. Sin embargo, en varios casos, las instituciones de educación superior han tenido que adaptarse a, y adoptar, estrategias específicas para poder transferir su plan de estudios presencial a un mundo digital, para lo cual no todos estaban preparados. Se analizan y proponen mejores prácticas, con el objetivo de ofrecer a los profesores de idiomas y, de hecho, a educadores de diferentes campos, criterios sobre cómo podrían alcanzar dicha sostenibilidad, a la luz de que el escenario educativo actual, donde la educación en línea se ha vuelto omnipresente, con seguridad permanecerá por más tiempo de lo esperado inicialmente. El análisis de la literatura demuestra que, a pesar de que hay una serie de docentes e instituciones alineados con los principios específicos de la enseñanza en línea, como seguir y abordar la pedagogía propia de esta modalidad, todavía hay margen de mejora, más específicamente en el uso de herramientas de autoría (como editores de video y otras herramientas multimodales).

Palabras claves: COVID-19, Enseñanza online EFL, Enseñanza online emergente, Educación online sostenible.

\section{Introducción.}

The COVID-19 pandemic has caused more traditional educational systems to experience a rather complex reality, especially when it comes to having to face the challenges of online education for which, in many cases, different settings were not fully prepared. Higher education is no stranger to this reality; most universities worldwide have been faced with tasks related to efficient implementation of online interventions amid the social distancing regulations that governments around the world have accordingly enacted (Bao, 2020; Murphy, 2020).

Several studies suggest that the process of going from emergency remote learning which according to Manfuso (2020) "is a rush job - an effort to mitigate the losses students and universities might experience... [by being] forced to completely abandon a semester's worth of work", to high-quality - and sustainable - online education should not be mistaken, as the 
former resorts to practices which are somewhat devised as proper. Well-structured online learning, on the other hand, features processes where in-advance efforts are more evident and suited to contextual realities: provision, or lack thereof, of digital technologies and devices, internet access and, sometimes even more significant, the knowledge on how to efficiently make use of this set of assets that currently shape online learning (Mavridi, 2020). In this respect, most university lecturers have proceeded to adopt strategies that deal with, up to a point, a more superficial use of online meeting software and authoring tools that may result unsuccessful if we think about the desired outcomes that students may - or not - demonstrate after they have completed their course work.

Added to this are the fundamental, worldwide changes that the pandemic has brought along; not only education is challenged with sudden shifts of paradigms, but so are issues that, for long, have not met agreements among world leaders. Wolff (2020) adds that the pandemic has proven to be a catalyst of so rooted, and for long argued decisions, such as how and why to stop emissions and therefore, climate change. This, then, leads our attention to the concept of sustainability, and its relationship with education. As expressed by Hakovirta and Denuwara (2020), the current society - in the broad sense of the term - is expected to act in such a way that their present needs are met in a mindful manner so that the ability of future generations to meet their own needs is not compromised. Education, on its sole end, should aim at being of - and offering - quality. Hence, efforts on the part of policy makers, education managers, and more directly, educators, should focus on the creation of interventions - from lesson planning to material creation and deployment, to sound application of online pedagogy - that facilitate a process of swift change that does not undermine the accomplishment of high quality education on the part of new generations of learners.

Recognizing Zhao (2020) it is also important to make it clear that even though online learning does not offer the exact same characteristics of face-to-face education, acknowledging its validity is a must. The current sanitary emergency has triggered the need for online education and inherent processes to be emergently put in place, and executed to the best of its affordances: simply put, the situation should be looked at and analyzed from all possible angles so that opportunities can be seen, where many would only assert inconveniences. As Zhao (2020, p.189) also adds "Online education cannot replace all functions schools play in our society, but it can do a lot more than being a lesser version of f $2 \mathrm{f}$ schooling".

Additionally, as much as it is important to have teachers who are well-trained in how to efficiently use digital technologies for their online lessons, attention should also be devoted to the training of students. The fact that current generations are believed to handle technology efficiently does not mean that they are completely aware of how to use technology for more academic purposes (Mavridi, 2020). Once again, Rahiem (2020) illustrates that "Emergency Remote Learning, the education that took place during school closure, [is] not online or virtual learning, since well-planned online learning experiences are substantially different from those that are delivered online in response to a crisis or catastrophe". In this study, the author resorted to university students' opinions to determine the impact of the sudden move from one, more normal mode if education to another, less planned - at least when it took 
place. This, of course, signals a yet untouched process, where students' insights on how to better deploy online learning should happen, for their own benefit.

It is necessary, then, to proceed in such a way that teachers and students feel supported, interventions are efficient and coherent, and content that is part of designed materials does not try to cover too much but only the essentials, for which training must be provided; followup processes are of course attached to this need. Under the criteria of how sustainable online education could be, it is important to minimize, as much as possible, the burdens created by time spent in planning and evaluating lessons, both for the synchronous and asynchronous aspects of this type of constructs. Materials must be aligned with reuse, recycling, and edition criteria, thus allowing for efforts to always be focused on offering, every time, better products, and enhanced processes of a well understood mode of education.

The set of suggestions that come forward try to be as comprehensive as possible, however, they do not represent, by any means, a final word into what should or could be done for teachers to be better equipped as they embark on online education, that goes from responding to emergencies, to becoming sound, effective and realistic interventions that aid education in the best possible way. As Avgerinou, \& Moros (2020) put forward, there is a great deal of innovation that should be more responsive - and visible - during the time that the pandemic is to last (which we cannot even predict right now). Even though the future is unknown, what occurs right now will certainly shape times to come.

\section{Methodology.}

For this literature review, articles submitted to different high-quality journals and digital publications since the declaration of the pandemic due to COVID-19 (11 March, 2020 WHO) have been analyzed, with the objective of capitalizing upon the experiences of different institutions worldwide, and their response to implementation of emergency online teaching. A first group of contributions were gathered according to what the exact response was, i.e., getting to know what initial measures were executed. Another collection dealt with perceived and evidenced differences between emergency online teaching and what could be considered more sustainable practices. Finally, a few other articles were selected in relation to what specific measures have been taken in the field of English language teaching (ELT). This process was conducive to proposing a set of suggestions and ideas that may well be considered by different stakeholders involved in online education, more essentially, language teachers for whom the task of online teaching - be it emergency or more developed versions - may have resulted frantic. A few documents corresponding to the last decade have also been used, given their importance in facilitating some initial concepts, necessary for a better outline of this work. 


\section{Results.}

This section introduces a set of recommendations, carefully explained, for English language teachers - but not exclusively for this group of practitioners - so that they are better able to implement their online lessons in such a way that they do not feel a burden as they continue to provide instruction to their students. In the case of Ecuador, and because of the current limitations, most contingency plans of higher education institutions seem to be confirming full closures until at least the end of the fall term (January 2021).

\section{Balance the amount of time dedicated to synchronous and asynchronous activities.}

In a lot of instances, taking the face-to-face curriculum to the online environment has meant that teachers thought - or were made to believe so - that absolutely every single activity designed for the everyday lessons should be somehow reproduced for the online encounter. This, whether administrators like it or not, is simply not possible. (Greenberg, 2020; Mavridi, 2020; Zhu \& Liu, 2020). Timewise, synchronous encounters, where interaction is expected to take place, should be planned, and designed so that class time is used efficiently to cover those points that are essential. Asynchronous activities - those which are not live - should be carefully thought of for students not to feel overwhelmed by excessive work that eventually teachers will have to mark - meaning even more time not dedicated to what could be better planned activities (George, 2020).

\section{Do expect the unexpected.}

It is important to understand that internet connections on both the side of teachers and students may experience difficulties during a lesson, or even at times when planning is taking place. A file may not open properly, or a video might be too heavy to upload onto the course VLE. There are even occasions when disruption caused by the slightest situation during connection time may turn it all into chaos (Atmojo \& Nugroho, 2020). In such cases, teachers should understand that there is nothing they should push. Sending the video through another means, after solving the size issue, or planning for the unexpected in mind - recognizing every possible scenario - are necessary steps that should be considered as lessons take place. This, for example, is a good start for the idea of making it all sustainable: planning with the idea that most of those materials and activities could not be as successful but, when they are, they could be recycled, reused or modified accordingly (Tzifopoulos, 2020). Under this line of work, the teacher will discover that things become less stressful, gaining expertise as they advance their interventions.

\section{Do not take things for granted.}

In the same way that teachers cannot fully rely on their internet connection, there are other important points that cannot be adjusted to a checklist. There is plenty of evidence that the provision of internet services, access to digital devices and even to more ever-present means 
of communication such as a mobile phone with access to instant messaging apps is not the same in all areas of a nation. The Ecuadorian case, unfortunately, is an example of this reality. According to the Ministry of Telecommunications and Information Society (2020), around one million students in Ecuador lack an internet connection, making it complicated for these students to get involved in online learning. Recommendations from this same Ministry to the Ministry of Education have been to think about the possibility of implementing teleeducation using state television networks, and also making connectivity more available for students in remote areas though the services offered by the National Telecommunications Company (CNT). In this context, thinking of other ways that are more adjusted to specific needs and audiences is a valuable practice on the part of educators. Again, the time dedicated to tackle those needs should be well balanced.

\section{Become a curator of tools, materials, and ideas.}

In his webinar, through RecetasTic (2020), Ávila recommends teachers to pay careful attention to the tools that really aid their teaching practice. In the same way that some students may not have problems using videoconferencing tools which are more user friendly - such as Zoom - there are others which have shown to be more complex. This is a moment when the teacher should rethink if a specific program or application should be changed for another, less complex. The author also considers important to allocate some time to get to know and "play" with authoring tools; mastering different software depends on the dedication the teacher applies to their craft, but more importantly, to the objective - learning outcome they have in mind. Will students have to dedicate more effort to learn how to handle the technology, or will they concentrate their efforts to comprehension of the proposed content? When it comes to ideas, teachers should be offered coaching and observation opportunities (Greenberg, 2020). For example, administrators or more skilled fellows could attend their colleagues' lessons to offer them live advice, or to debrief later. Conversely, teachers who feel like doing so could greatly benefit from sessions where answers to even "simple" questions are offered.

\section{Possessing the necessary digital skills means well prepared teachers - and students.}

Where you prepared for the new teaching scenario that the pandemic brought about? After almost five months of working fully online, have your digital skills improved in any way? Even with the demands of education in the XXI century, that have been more noticeable during the last five-year period, there are teachers who have never taught and students who have never had an online lesson. Indeed, there have been institutions worried about their teachers and their in-time training so that they could feel at ease when starting their work online. Nevertheless, as this is a two-way process, students should also become aware of what is expected from them when facing online activities. Mavridi (2020) suggests allocating at least a few days at the beginning of a school term to create team building and digital skills. This would help all of the actors involved to perform in a more improved way. 


\section{Training as a permanent enabling act.}

Be it offered, ideally, from the institution where the teacher works, or from opportunities looked by themselves, teachers should constantly be trained and allowed to perform in such a way that changes in their practice are not expected to happen overnight. While it is true that new knowledge should be exercised from the moment it is grasped, it will take some time before the teacher finds it easier to implement the technology at hand - and this is completely normal. There is no need to rush a process which, as discussed previously, is not the same in all cases. When teachers are new to online teaching, it is important to design a learning path that really proves to be useful to take them from, sometimes nothing, to a sound knowledge of instructional design and necessary digital skills for online teaching (O'Keefe, Rafferty, Gunder, \& Vignare, 2020; Baghdadi, 2020).

\section{Decide on the most appropriate content for language teaching.}

With a plethora of resources available online, there is a broad range of materials that EFL teachers can choose from to deliver their lessons. Fansury, Januarty, \& Ali Wira Rahman (2020) state that while this task might be time-consuming, there is no way that a teacher of English could complain about not having enough assets handy. When more accurate information is offered by careful selection of materials, students evidence improved understanding and a higher degree of motivation is also evident.

\section{Think of a swift move to task-based learning.}

Egbert (2020), states that in the times of pandemic, designing lessons that involve completion of a specific task, where the language focus is included, may well play a key factor when having students comprehend the target language better. Creativity plays an important role in this context. As Egbert continues, "using engaging tasks can also help to keep teachers engaged and demonstrating positive attitudes, too". This means that in all cases, it is necessary to, once again, think of the audience for whom the tasks are being designed so that the group and the teacher feel a permanent compromise in achieving the proposed, final result.

The above points are, more than ever, aligned with what Sener (2010) proposed in relation to the attainment of full scale of online education:

Practically all higher education students will experience online education in some form during their collegiate career, and college students will be able to take online or blended degree programs and certificates in almost any subject. Full scale online education will occur as the result of compounded growth, increased familiarity and acceptance, various models of scalability, and possible wildcards which may accelerate growth. Online education will also attain full scale by becoming fully 
integrated into mainstream education. This transformation is necessary for online learning to reach its potential to improve the quality of education (p. 3).

In this sense, the COVID-19 pandemic has accelerated Sener's predictions, proposing a type of online education that is actually proving to be essential, transformational, and without a doubt, the new normal for which all actors of education must be prepared, and adjust to. In similar lines, Geith \& Vignare (2008) stated that accessibility and availability of online learning, using open educational resources (OER), would have increased the demand and interest of students in online education. As it is now clear, they were not far from a reality that is now visible and consolidating as moths go by.

\section{Conclusiones:}

- As it has been discussed, emergency online teaching should not be confused with well designed, sustainable online education. First, the former is implemented as a response to emergency situations, as is the pandemic resulting from the spread of COVID-19 virus. While it may be a good start for future endeavors, conducive to the latter, it is necessary to clearly understand the more complex process involved in making online education sustainable.

- Furthermore, and based on the above discussion, asking if whether online education works becomes meaningless: right now it is proving not only to be worth the effort, but also to offer answers in times where the future is certainly unknown; little by little, teachers, students and educational administrators are understanding that, in the new normal, online education is ever-present, and will not fade for the time being and beyond.

- Last, but not least, it must be understood that the fact that implementation of online interventions has been called to as an obligation from teachers does not mean that they are ready - well educated and aware - to use specific digital technologies. If anything, teachers should be offered in time training that relates to their contextual realities, and that provides them with strategies that do allow to enquire about how applying certain idea may not have the exact same result as it would for another colleague. Ultimately, the field in which this happens corresponds to what would be more universal practices, which are not exclusive of ELT.

\section{Referencias bibliográficas.}

Atmojo, A. E. P., \& Nugroho, A. (2020). EFL Classes Must Go Online! Teaching Activities and Challenges during COVID-19 Pandemic in Indonesia. Register Journal, 13(1), 49-76. 
Avgerinou, M. D., \& Moros, S. E. (2020) The 5-Phase Process as a Balancing Act during Times of Disruption: Transitioning to Virtual Teaching at an International JK-5 School.

Baghdadi, Z. D. (2011). Best practices in online education: Online instructors, courses, and administrators. Turkish Online Journal of Distance Education, 12(3), 109-117.

Bao, W. (2020). COVID-19 and online teaching in higher education: A case study of Peking University. Human Behavior and Emerging Technologies, 2(2), 113-115.

Baghdadi, Z. D. (2011). Best practices in online education: Online instructors, courses, and administrators. Turkish Online Journal of Distance Education, 12(3), 109-117.

Fansury, A. H., Januarty, R., \& Ali Wira Rahman, S. (2020). Digital Content for Millennial Generations: Teaching the English Foreign Language Learner on COVID-19 Pandemic. Journal of Southwest Jiaotong University, 55(3).

Geith, C., \& Vignare, K. (2008). Access to Education with Online Learning and Open Educational Resources: Can They Close the Gap? Journal of asynchronous learning networks, 12(1), 105-126.

Greenberg, B. (2020). What we've learned from distance learning, and what it means for the future. Education Next.

George, M. L. (2020). Effective Teaching and Examination Strategies for Undergraduate Learning During COVID-19 School Restrictions. Journal of Educational Technology Systems, 0047239520934017.

Hakovirta, M., \& Denuwara, N. (2020). How COVID-19 redefines the concept of sustainability.

Manfuso, L. G. (2020). From Emergency Remote Teaching to Rigorous Online Learning.

https://edtechmagazine.com/higher/article/2020/05/emergency-remote-teaching-rigorousonline-learning-perfcon

Mavridi, S. (2020). From emergency remote teaching to sustainable online education. [Plenary talk]. English Australia Ed-Tech SIG Symposium.

Ministerio de Telecomunicaciones y de la Sociedad de la Información (2020, marzo). El Ministro Michelena explicó en la Asamblea Nacional los avances en TIC para acceder a más conectividad. https://www.telecomunicaciones.gob.ec/el-ministro-michelenaexplico-en-la-asamblea-nacional-los-avances-en-tic-para-acceder-a-masconectividad/ 
Murphy, M. P. (2020). COVID-19 and emergency eLearning: Consequences of the securitization of higher education for post-pandemic pedagogy. Contemporary Security Policy, 1-14.

O'Keefe, L., Rafferty, J., Gunder, A., \& Vignare, K. (2020). Delivering High-Quality Instruction Online in Response to COVID-19: Faculty Playbook. Online Learning Consortium.

Rahiem, M. D. (2020). The Emergency Remote Learning Experience of University Students in Indonesia amidst the COVID-19 Crisis. International Journal of Learning, Teaching and Educational Research, 19(6).

RecetasTic - Iniciativa EDUvsCOVID-19. (2020). Webinar 16: ¿Qué habilidades debería tener como docente online? Tips y consejos prácticos - Stalyn Ávila Herrera, MA. Disponible en: https://youtu.be/T_I3bnJzM4U

Sener, J. (2010). Why online education will attain full scale. Journal of Asynchronous Learning Networks, 14(4), 3-16.

Tzifopoulos, M. (2020). In the shadow of Coronavirus: Distance education and digital literacy skills in Greece. International Journal of Social Science and Technology, $5(2), 1-14$.

Wolff, L. A. (2020). Sustainability Education in Risks and Crises: Lessons from Covid-19.

World Health Organization - WHO (2020, March). WHO Director-General's opening remarks at the media briefing on COVID-19. https://www.who.int/dg/speeches/detail/who-director-general-s-opening-remarks-atthe-media-briefing-on-covid-19---11-march-2020

Zhao, Y. (2020). Tofu Is Not Cheese: Rethinking Education Amid the COVID-19 Pandemic.

Zhu, X., \& Liu, J. (2020). Education in and After Covid-19: Immediate Responses and LongTerm Visions. Postdigital Science and Education, 1-5.

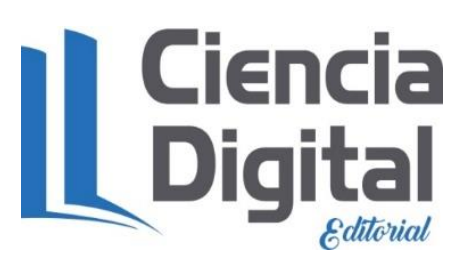




\section{PARA CITAR EL ARTÍCULO INDEXADO.}

Campaña Días, D. C., Robalino Araujo, M. C., Porras Pumalema, S. P., \& Bonilla Yucailla, D. A. (2020). Creating a path from emergency online teaching to sustainable online education. Explorador $\quad$ Digital, $\quad 4(3), \quad 241-251$. https://doi.org/10.33262/exploradordigital.v4i3.1348

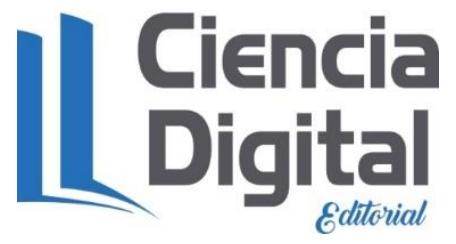

El artículo que se publica es de exclusiva responsabilidad de los autores y no necesariamente reflejan el pensamiento de la Revista Explorador Digital.

El artículo queda en propiedad de la revista y, por tanto, su publicación parcial y/o total en otro medio tiene que ser autorizado por el director de la Revista Explorador Digital.
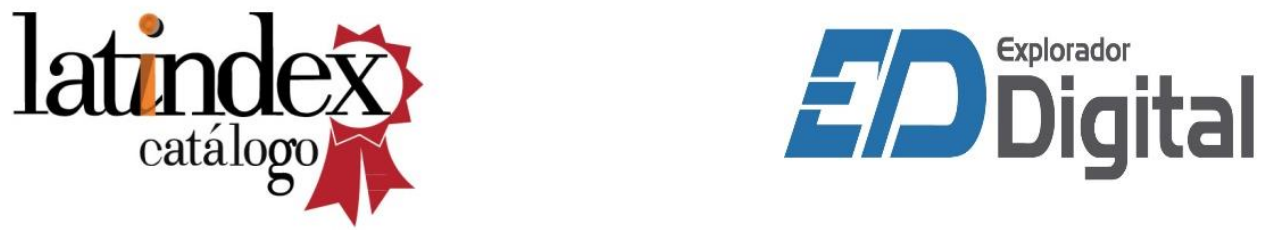